\title{
RISK ASSESSMENT OF ANTIBIOTIC PREVALENCE IN DRINKING WATER AND ITS IMPACTS ON HUMAN HEALTH IN CHINA
}

\author{
LYU, J. ${ }^{1,2,3}-$ YANG, L. S. ${ }^{2,3}-$ CHEN, Y. Y. ${ }^{1}-$ YE, B. X. ${ }^{1}-$ ZHANG, L. $.^{1 *}-$ WANG, L. ${ }^{2 *}$ \\ ${ }^{1}$ China CDC Key Laboratory of Environment and Population Health, National Institute of \\ Environmental Health, Chinese Center for Disease Control and Prevention, No.29 Nanwei \\ Road, Xicheng District, Beijing 100050, PR China \\ (e-mail: lvjia@nieh.chinacdc.cn; phone: +86-10-5093-0228; fax: +86-10-5093-0228) \\ ${ }^{2}$ Key Laboratory of Land Surface Pattern and Simulation, Institute of Geographical Sciences \\ and Natural Resources Research, Chinese Academy of Sciences, 11A, Datun Road, Chaoyang \\ District, Beijing 100101, PR China \\ (e-mail: yangls@igsnrr.ac.cn; phone: +86-10-6488-9276; fax: +86-10-6485-4230) \\ ${ }^{3}$ University of Chinese Academy of Sciences, 19(A) Yuquan Road, Shijingshan District, Beijing \\ 100049, PR China \\ *Corresponding authors \\ e-mail/phonelfax: zhanglan@nieh.chinacdc.cn/+86-10-5093-0224/+86-10-5093-0228; \\ wangli@igsnrr.ac.cn/+86-10-6485-4841/+86-10-6485-4230
}

(Received 29 $9^{\text {th }}$ Jul 2020; accepted $19^{\text {th }}$ Nov 2020)

\begin{abstract}
Drinking water is a known potential source of human exposure to antibiotics. However, risk of antibiotic exposure from drinking water has not been sufficiently quantified. We measured the levels of 23 antibiotics in drinking water from 12 cities of China during the summer and winter seasons, quantifying exposure doses and health risk quotients (HRQ) of antibiotic exposure via drinking water. High detection rates (above 70\%) of macrolides (MLs), sulfonamides and fluoroquinolones were observed during summer season, with median concentrations of $0.26 \mathrm{ng} / \mathrm{L}, 0.59 \mathrm{ng} / \mathrm{L}$ and $0.36 \mathrm{ng} / \mathrm{L}$, respectively, while only MLs were observed with a high detection rate in winter (median concentration $0.46 \mathrm{ng} / \mathrm{L}$ ). Total antibiotic exposure via drinking water ranged from $0.0036 \mathrm{ng} / \mathrm{kg} / \mathrm{day}$ to $4.36 \mathrm{ng} / \mathrm{kg} / \mathrm{day}$ in summer and from $0.0046 \mathrm{ng} / \mathrm{kg} / \mathrm{day}$ to $1.12 \mathrm{ng} / \mathrm{kg} /$ day in winter. High median antibiotic exposures were observed in Chaohu, Huainan and Guangzhou in summer and in Mudanjiang in winter. Of the 18 detected antibiotics, enrofloxacin, ciprofloxacin, sarafloxacin and roxithromycin had an HRQ $\geq 0.01$. Drinking water is one of the principal pathways for human exposure to antibiotics. Accordingly, management of antibiotic exposure from drinking water should be a high public health priority, and the accompanying health risks merit greater attention from public health authorities.
\end{abstract}

Keywords: pollution, exposure, macrolides, sulfonamides, fluoroquinolones

Abbreviations: ADD: average daily potential dose, ADI: acceptable daily intake, DWTP: drinking water treatment plant, GP: glycopeptide, HLB: hydrophilic-lipophilic balance, HRQ: health risk quotient, LN: lincosamide, ML: macrolide, ND: not detected, QN: fluoroquinolone, RSC: relative source contribution, SA: sulfonamide, SPE: solid phase extraction, UPLC-MS/MS: ultra-performance liquid chromatography-tandem mass spectrometer, $\beta \mathrm{L}$ : $\beta$-lactam

\section{Introduction}

Antibiotics include a range of powerful medication ingredients that can destroy or slow the growth of bacteria and are extensively used to treat human and animal diseases and to promote animal growth (Le Page et al., 2017). The rising rate of antibiotic use has led to the contamination of potable water sources from natural bodies of water 
receiving effluents from municipal wastewater treatment plants (hospital and community, Aga et al., 2016), agricultural sources (aquaculture, husbandry, Kümmerer, 2009), and the pharmaceutical industry (de Jesus Gaffney et al., 2015). Incomplete removal of antibiotics by conventional technologies (e.g., flocculation, sedimentation and disinfection) in drinking water treatment plants (DWTPs) leaves antibiotic residues in tap water, which now constitutes continuous human exposure to antibiotics (Yang et al., 2011). It is imperative to evaluate the exposure and health risks of antibiotics in drinking water.

In recent years, the issue of human health risk due to overuse of antibiotics has attracted substantial attention from the general public worldwide (Knapp et al., 2010). Antibiotics are understood to pose human health risks, including hypersensitive reactions, abnormalities in digestive functioning (Bedford, 2000), development and spread of antibiotic-resistant bacteria (Gullberg et al., 2011), and protracted toxic effects due to long-term low-level exposure (Sarmah et al., 2006). The occurrence of antibiotics in aquatic environments and drinking water is well-documented in developed countries including the USA (Benotti et al., 2009) and in the European Union (Carmona et al., 2014). China is one of the world's largest producers and consumers of antibiotics (Zhang et al., 2015). Previous investigations on antibiotic residues in aquatic environment have provided evidence that China has problems of antibiotic pollution (Ma et al., 2015; Xu, 2018). Thus, concerns are rising about antibiotic exposure from drinking water. However, studies measuring exposure to antibiotics in drinking water and associated health risks in China are limited.

The objectives of this study were to: (1) quantify the levels of 23 antibiotics in drinking water from 12 cities in different water basins in China, including seasonal and spatial distributions; (2) assess human exposure to antibiotics in drinking water in China; and (3) estimate the potential risks of antibiotic exposure via drinking water in the Chinese population.

\section{Materials and methods}

\section{Water sampling and analysis}

Tap water in China comes from the public water system and is treated at DWTPs for drinking and other household usages. Tap water samples were collected from 12 cities located in seven large river basins, three key lake basins and two key reservoir areas of China. Of the 12 cities sampled, 10 (Yibin, Lanzhou, Huainan, Shenyang, Mudanjiang, Guangzhou, Wuxi, Kunming, Chaohu and Chongqing) are prefecture-level cities with at least one million inhabitants and are located in the Yangtze River Basin, Yellow River Basin, Huaihe River Basin, Liaohe River Basin, Songhua River Basin, Pearl River Basin, Taihu Lake Basin, Dianchi Lake Basin, Chaohu Lake Basin, and Three Gorges Reservoir Area, respectively. Based on the population and number of DWTPs in each of these cities, five representative DWTPs were selected from each city for collection of tap water samples in corresponding water supply areas. The two remaining cities, Danjiangkou and Korla, are county-level cities with approximately one hundred thousand inhabitants and are located in the Danjiangkou Reservoir Area and Northwest River Basin, respectively. Based on the population and number of DWTPs in each of these cities, three DWTPs in Danjiangkou and one DWTP in Korla were selected for tap water sampling in corresponding water supply areas. This sampling plan yielded a total of 54 sampling points, from which tap water samples were collected in sunny or cloudy 
weather in January and July 2017. The sampling locations are shown in Figure 1. Water samples were collected manually by qualified personnel in $2000 \mathrm{~mL}$ amber glass bottles with screw caps. The bottles were washed with water, methanol and ultrapure water and then dried prior to sample collection. A total of $30 \mathrm{mg}$ of ascorbic acid was added for each liter of water as a pharmaceutical preservative (Lv et al., 2019). The water samples were maintained in dark conditions at $4{ }^{\circ} \mathrm{C}$ from the time of collection through reception and analysis at the laboratory.

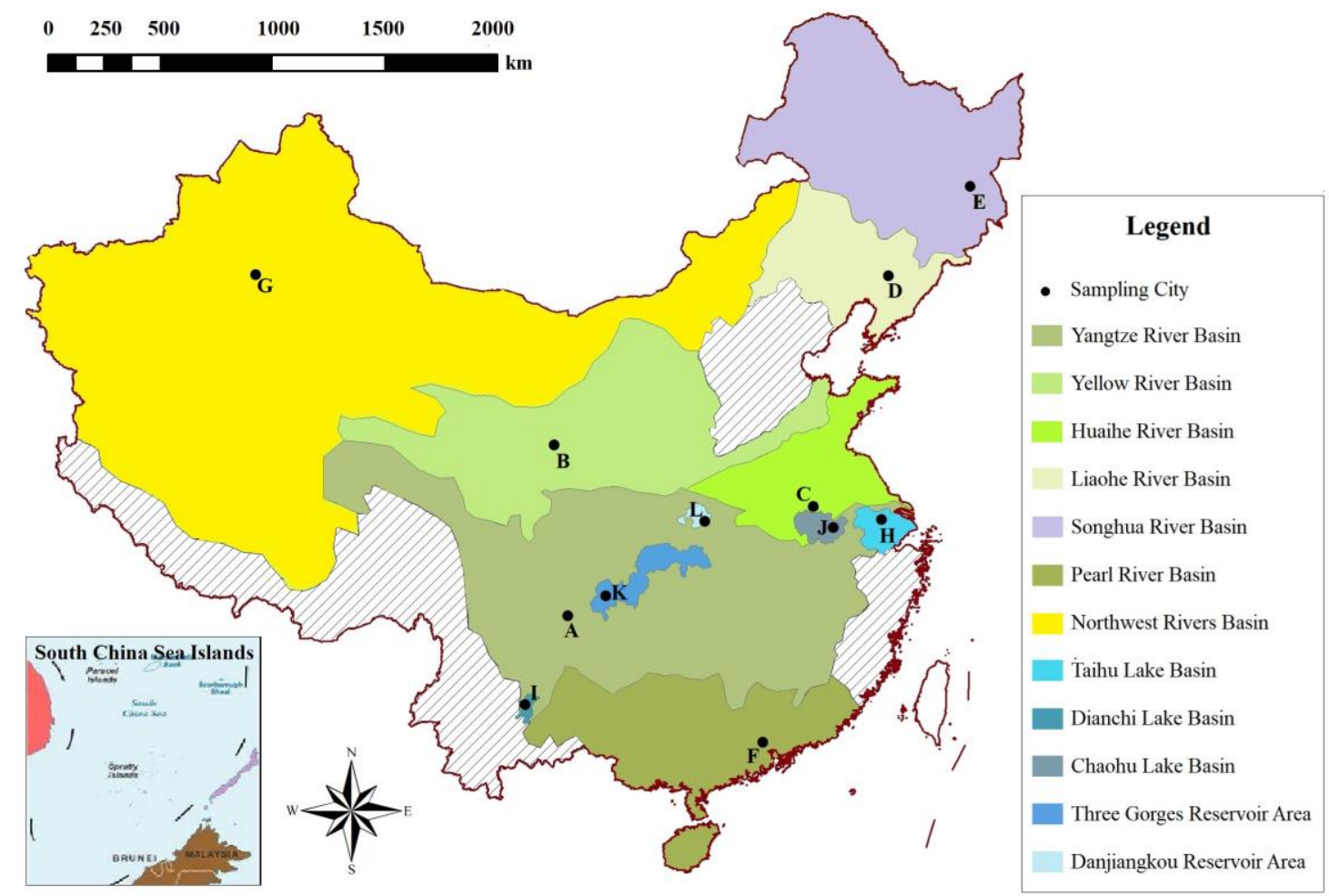

Figure 1. Sampling locations, including cities and river basins. A, Yibin; B, Lanzhou; C, Huainan; D, Shenyang; E, Mudanjiang; F, Guangzhou; G, Korla; H, Wuxi; I, Kunming; J,

Chaohu; K, Chongqing; L, Danjiangkou

Twenty-three antibiotics of six different classes commonly used in China were analyzed, including four $\beta$-lactams ( $\beta$ Ls), three macrolides (MLs), eight sulfonamides (SAs), six fluoroquinolones (QNs), one lincosamide (LN) and one glycopeptide (GP). Information on standards for analytes is listed in Table Al in the Appendix. Target analytes were extracted from water samples using solid phase extraction and then analyzed by ultra-performance liquid chromatography-tandem mass spectrometer. Field blanks and method blanks were created to identify any contaminant from the sampling site and analysis process. Recovery and precision were used to validate the method performance. Analysis process and its quality assurance were described in detail in the Appendix.

\section{Exposure assessment via drinking water consumption}

Drinking and dermal absorption are the main contaminant intake and uptake routes for human exposure to antibiotics through drinking water consumption. The average 
daily potential dose (ADD) was used to evaluate antibiotic exposure through drinking and dermal absorption during water consumption, consumption of foods containing or cooked using water, and use of water for food washing and household activities including brushing teeth, bathing, and washing clothes.

ADD through intake water $\left(\mathrm{ADD}_{\mathrm{dw}}\right)$ was calculated using Equation 1:

$$
\mathrm{ADD}_{\mathrm{dw}}=\frac{\mathrm{c}_{\mathrm{dw}} \times \operatorname{IngR} \times \mathrm{EF} \times \mathrm{ED}}{\mathrm{BW} \times \mathrm{AT} \times 1000}
$$

where $\mathrm{ADD}_{\mathrm{dw}}$ is the ADD from intake of water $(\mu \mathrm{g} / \mathrm{kg} /$ day $), \mathrm{C}_{\mathrm{dw}}$ is the concentration of antibiotics in drinking water $(\mathrm{ng} / \mathrm{L})$, IngR is the ingestion rate (L/day), including both direct and indirect ingestion, EF is the exposure frequency (days/year), ED is the exposure duration (years), BW is body weight (kg), and AT is averaging time (days). To reduce uncertainties in exposure variation between different geographical areas, across seasons, and between men and women, the IngR values corresponding to area, season and sex as well as the sex-specific BW value in China according to the Exposure Factors Handbook of Chinese Population (China EPA, 2009; area, season and sexspecific values are shown in Table A2) were used.

ADD through dermal absorption with water use $\left(\mathrm{ADD}_{\text {dermal }}\right)$ was calculated using Equation 2:

$$
\mathrm{ADD}_{\text {dermal }}=\sum_{\mathrm{i}=1}^{9} \frac{\mathrm{DA}_{\text {event-i }} \times \mathrm{SA}_{\mathrm{i}} \times \mathrm{EF}_{\mathrm{i}} \times \mathrm{ED}_{\mathrm{i}}}{\mathrm{BW} \times \mathrm{AT}_{\mathrm{i}}}
$$

where $\mathrm{ADD}_{\text {dermal }}$ is the $\mathrm{ADD}$ through dermal absorption $(\mu \mathrm{g} / \mathrm{kg} / \mathrm{day})$. Dermal exposure was calculated from nine daily activities, including washing hands, face, hair, feet; washing vegetables, dishes, and clothes; bathing, and swimming. $\mathrm{DA}_{\text {event-i }}$ refers to the absorbed dose from one event $\left(\mu \mathrm{g} / \mathrm{cm}^{2} / \mathrm{day}\right)$, as calculated using Equation 3. SA $\mathrm{A}_{\mathrm{i}}$ refers to the skin surface area available for contact $\left(\mathrm{cm}^{2}\right)$, according to the Exposure Factors Handbook of Chinese Population (China EPA, 2009; values summarized in Table A3). $\mathrm{EF}_{\mathrm{i}}$ refers to the exposure frequency (days/year), $\mathrm{ED}_{\mathrm{i}}$ to the exposure duration (years), $\mathrm{BW}$ to body weight $(\mathrm{kg})$, and $\mathrm{AT}_{\mathrm{i}}$ to averaging time (days). $\mathrm{DA}_{\text {event-i }}$ was calculated as follows:

$$
\mathrm{DA}_{\text {event-i }}=\mathrm{K}_{\mathrm{p}} \times \mathrm{C} \times \mathrm{T} \times 10^{-6}
$$

where $K_{p}$ is the permeability coefficient $(\mathrm{cm} / \mathrm{hr}), \mathrm{C}$ is the chemical concentration in water that is in contact with the skin (ng/L), and $\mathrm{T}$ is the time of contact (hours/day), which was determined from references on water usage habits in northern and southern China (Duan et al., 2010; Huang et al., 2017), as summarized in Table A4.

It is difficult to obtain permeability coefficients of antibiotics directly from references. Accordingly, we used a model developed by ten Berge (2010) and recommended by Brown et al. (2016) in a study of eight models for calculating $\mathrm{K}_{\mathrm{p}}$ by Equation 4:

$$
\log \mathrm{K}_{\mathrm{p}}=-2.80+0.66 \log \mathrm{K}_{\mathrm{ow}}-0.0056 \mathrm{MW}
$$


where $\mathrm{K}_{\mathrm{ow}}$ is the octanol/water partition coefficient of the target antibiotic and MW is the molecular weight $(\mathrm{g} / \mathrm{mole}) . \mathrm{K}_{\mathrm{ow}}$ and $\mathrm{MW}$ of target antibiotics are summarized in Table A5.

The total exposure to each antibiotic through drinking water consumption (ADD) was defined as the sum of $\mathrm{ADD}_{\mathrm{dw}}$ and $\mathrm{ADD}_{\text {dermal. }}$ The $\mathrm{ADD}$ for the population of one area in a given season was calculated as the sex ratio-weighted average ADD. Sex ratios for each city were taken from the China Statistical Yearbook (National Bureau of Statistics, 2018; sex ratio values summarized in Table A6).

\section{Health risk assessment}

A health risk quotient (HRQ) is the ratio of a point estimate of exposure and a point estimate of health effects. HRQ for each antibiotic was calculated for each antibiotic by dividing its ADD by the acceptable daily intake (ADI) or risk-specific dose (RSD). HRQs were calculated using the most restrictive ADI or RSD for each antibiotic, which were adopted from provisional values established in the literature or derived using previously applied toxicological, microbiological or therapeutic approaches (Leung et al., 2013; Bengtsson-Palme and Larsson, 2016). The ADIs or RSDs used for HRQ calculation of each antibiotic are described in Table A7. The HRQ of each antibiotic in each city $\left(\mathrm{HRQ}_{\mathrm{ac}}\right)$ was defined as the maximum HRQ of the antibiotic among all sampling points in the city. The total HRQ in each city $\left(\mathrm{HRQ}_{\mathrm{tc}}\right)$ was the maximum value of the total HRQ for each sampling point $\left(\mathrm{HRQ}_{\mathrm{tp}}\right)$, where $H R Q_{\mathrm{tp}}$ was the sum of HRQs for each antibiotic from each sampling point.

\section{Results}

\section{Distribution of antibiotics in drinking water}

Of 23 antibiotics quantified in this study, seventeen were detected in drinking water samples during the summer season, including three MLs, eight SAs, four QNs, one LN and one GP. Ten antibiotics were detected during the winter season, including one $\beta \mathrm{L}$, two MLs, six SAs and one QN (Fig. 2). The detection rates and concentrations of antibiotics are summarized in Table A8. Detection rates in drinking water samples were above $70 \%$ during the summer for MLs, SAs and QNs, with median concentrations of $0.26 \mathrm{ng} / \mathrm{L}, 0.59 \mathrm{ng} / \mathrm{L}$ and $0.36 \mathrm{ng} / \mathrm{L}$. During the winter, detection rates were above $70 \%$ only for MLs, with a median concentration of $0.46 \mathrm{ng} / \mathrm{L}$.

The concentration levels of antibiotics in drinking water samples varied by city and season (Fig. 3; Table A8). In the summer, MLs were detected with a high median concentration of $10.12 \mathrm{ng} / \mathrm{L}$ in Guangzhou; the dominant ML was tylosin (range 6.82$15.04 \mathrm{ng} / \mathrm{L}$ ). SAs and QNs were detected with high median concentrations of $2.73 \mathrm{ng} / \mathrm{L}$ and $3.41 \mathrm{ng} / \mathrm{L}$ respectively in Chaohu; the dominant antibiotics in these classes were sulfadiazine (0.81-5.20 ng/L), ciprofloxacin (1.17-1.94 ng/L), enrofloxacin (1.07$2.11 \mathrm{ng} / \mathrm{L})$ and sarafloxacin $(0.29-4.21 \mathrm{ng} / \mathrm{L})$. SAs and QNs were also detected with high median concentrations of $1.73 \mathrm{ng} / \mathrm{L}$ and $6.40 \mathrm{ng} / \mathrm{L}$, respectively, in Huainan; the dominant antibiotics in these classes were sulfamethoxazole $(0.54-21.93 \mathrm{ng} / \mathrm{L})$, sulfamethazine (0.11-7.63 ng/L), sulfadoxin (0.070-16.90 ng/L), ciprofloxacin (0.87$3.63 \mathrm{ng} / \mathrm{L})$, enrofloxacin (1.97-4.47 ng/L) and sarafloxacin (0.82-1.64 ng/L). In the winter, SAs and MLs were detected with high median concentrations of $10.19 \mathrm{ng} / \mathrm{L}$ and $2.23 \mathrm{ng} / \mathrm{L}$, respectively, in Mudanjiang; the dominant antibiotics in these classes were 
sulfamethoxazole (1.27-6.82 ng/L), sulfadiazine (0.39-3.78 ng/L), trimethoprim (1.78$3.44 \mathrm{ng} / \mathrm{L})$ and roxithromycin $(0.39-17.28 \mathrm{ng} / \mathrm{L})$. SAs were also detected in Lanzhou, Huainan and Chongqing with high median concentrations of $7.40 \mathrm{ng} / \mathrm{L}, 3.03 \mathrm{ng} / \mathrm{L}$ and $2.23 \mathrm{ng} / \mathrm{L}$, respectively; the dominant $\mathrm{SA}$ in these cities was sulfamethoxazole (concentrations of $0.74-13.38 \mathrm{ng} / \mathrm{L}, 1.16-13.57 \mathrm{ng} / \mathrm{L}$ and $0.29-4.57 \mathrm{ng} / \mathrm{L}$, respectively).

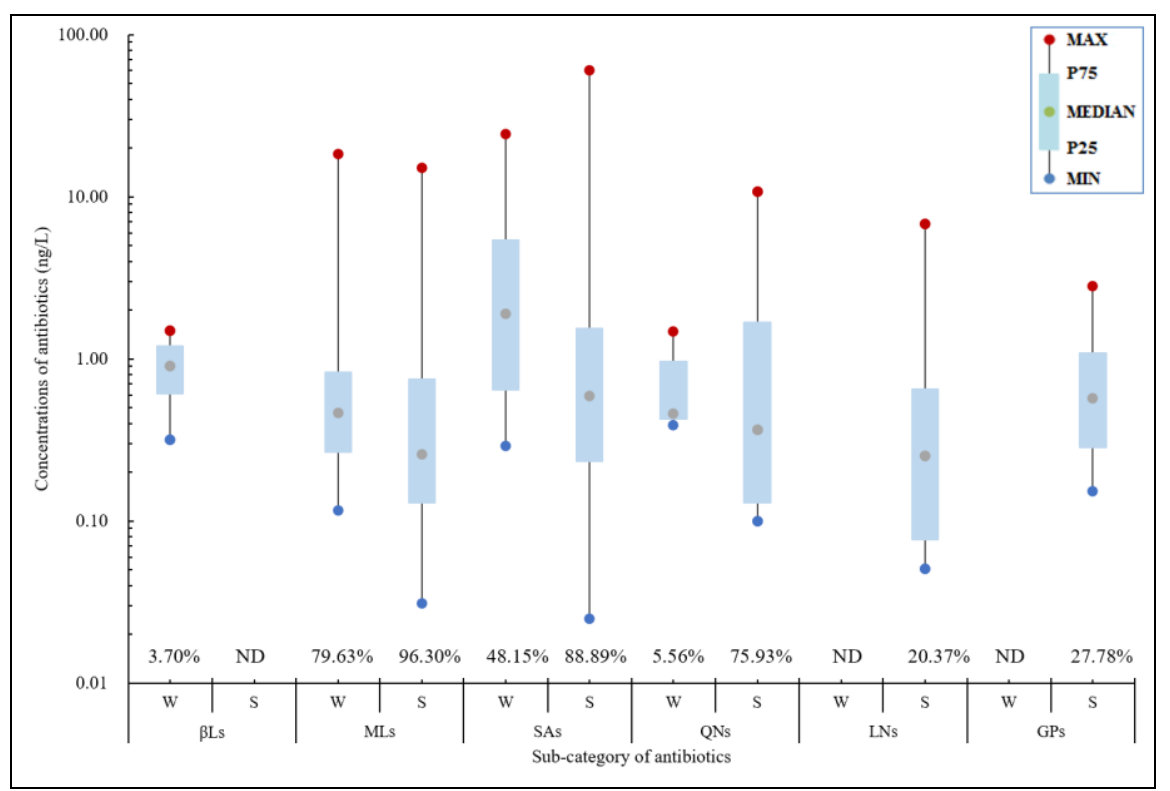

Figure 2. Concentrations of antibiotics in drinking water samples in China. $\beta L s, \beta$-lactams; MLs, macrolides; SAs, sulfonamides; QNs, fluoroquinolones; LNs, lincosamides; GPs, glycopeptides; $W$, winter; $S$, summer; $N D$, not detected
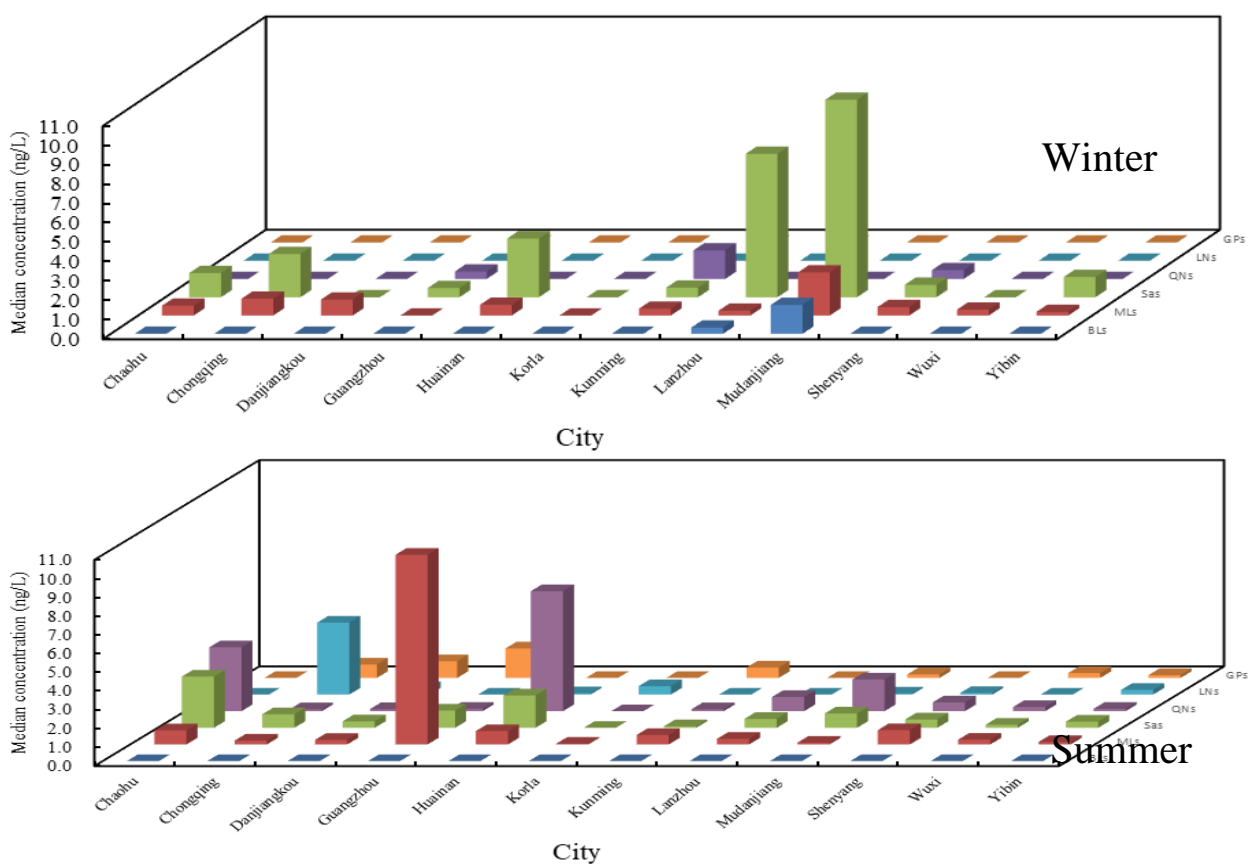

Figure 3. Spatiotemporal distribution of six sub-categories of antibiotics in drinking water by city. $\beta$ Ls, $\beta$-lactams; MLs, macrolides; SAs, sulfonamides; QNs, fluoroquinolones; LNs, lincosamides; GPs, glycopeptides. Antibiotics were not detected in Korla in winter 


\section{Human exposure to antibiotics contaminated drinking water consumption}

Exposure to antibiotics from drinking water varied across cities (Fig. 4). The median exposure dose to total antibiotics from drinking water was $0.071 \mathrm{ng} / \mathrm{kg} / \mathrm{day}$ during summer season and $0.029 \mathrm{ng} / \mathrm{kg} /$ day during winter season. During summer, the highest median antibiotic exposure was observed in Chaohu $(0.68 \mathrm{ng} / \mathrm{kg} /$ day $)$, where exposure mainly derived from exposure to SAs (24.61-98.07\%) and QNs (1.16-73.16\%). Relatively high antibiotic exposure levels were also observed in Huainan, with a median dose of $0.62 \mathrm{ng} / \mathrm{kg} / \mathrm{day}$, also derived mainly from exposure to SAs (12.62-84.68\%) and QNs (7.93-77.79\%). Finally, relatively high exposure levels were observed in Guangzhou (median dose $0.48 \mathrm{ng} / \mathrm{kg} / \mathrm{day}$ ), where exposure was mainly derived from MLs (3.42-90.57\%). The highest exposure in winter was observed in Huainan (median dose $4.36 \mathrm{ng} / \mathrm{kg} / \mathrm{day}$ ). During winter, the highest median exposure level was observed in Mudanjiang (0.47 ng/kg/day), mainly derived from SAs (39.56-79.83\%) and MLs (16.00-60.44\%).

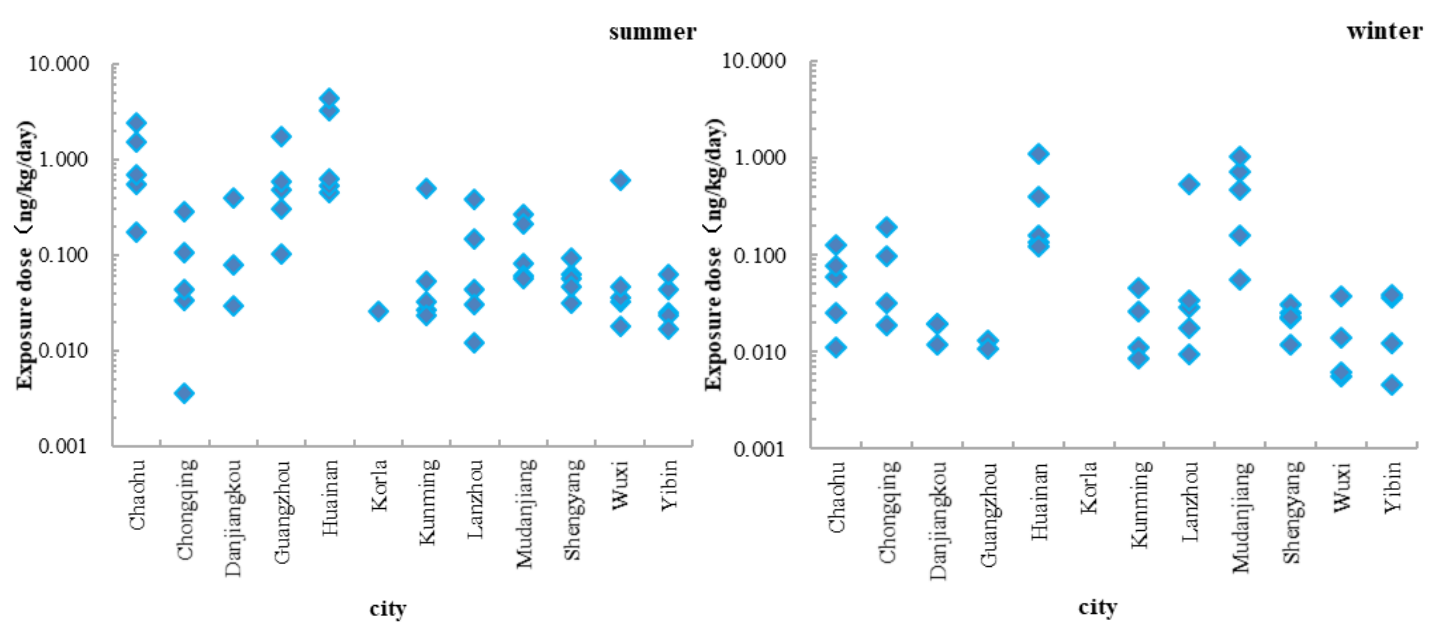

Figure 4. Total antibiotic exposure via drinking water by city, sampling point and season

Antibiotics were divided according to human or veterinary usage. Of 18 antibiotics detected in drinking water across summer and winter, 11 were used for both humans and animals, while 7 were used only for animals. Overall detection rates of veterinary antibiotics were $87.04 \%$ in the summer and $14.81 \%$ in the winter. Relatively high proportions of exposure to veterinary antibiotics were observed in Huainan, Guangzhou, Chaohu, Kunming and Mudanjiang during the summer, ranging from 22.71-58.44\%, 44.73-97.64\%, 16.14-57.41\%, 40.51-97.30\% and 30.91-69.31\%, respectively (Fig. 5).

\section{Risk assessment of antibiotics in drinking water}

Among the eighteen antibiotics detected in at least one sample, HRQs for each antibiotic at each sampling point ranged from $1.8 \times 10^{-8}$ to 0.13 in the summer and from $3.2 \times 10^{-7}$ to 0.020 in winter. The maximum HRQ of each antibiotic in each city by season and the $\mathrm{HRQ}_{\mathrm{tc}}$ are shown in Figure 6. Antibiotics with $\mathrm{HRQ} \geq 0.01$ included three QNs (enrofloxacin, ciprofloxacin, sarafloxacin) and one ML (roxithromycin), with $\mathrm{HRQ}_{\mathrm{ac}}$ ranging from $4.4 \times 10^{-3}$ to $0.13,4.6 \times 10^{-3}$ to $0.11,2.2 \times 10^{-4}$ to $1.5 \times 10^{-2}$ and $5.8 \times 10^{-5}$ to $1.8 \times 10^{-2}$, respectively. Antibiotics with $\mathrm{HRQ} \geq 0.0001$ and $<0.01$ 
included one $\beta \mathrm{L}$ (cephalecxin), two MLs (clarithromycin and tylosin), three SAs (trimethoprim, sulfamethoxazole and sulfamethazine), lincomycin and virginiamycin, with $\mathrm{HRQ}_{\mathrm{ac}}$ ranging from $9.3 \times 10^{-5}$ to $3.9 \times 10^{-4}, 5.1 \times 10^{-4}$ to $4.8 \times 10^{-3}, 2.1 \times 10^{-3}$ to $4.5 \times 10^{-3}, 2.8 \times 10^{-4}$ to $9.4 \times 10^{-3}, 1.2 \times 10^{-5}$ to $2.7 \times 10^{-3}, 5.5 \times 10^{-6}$ to $2.9 \times 10^{-4}$, $3.3 \times 10^{-5}$ to $3.5 \times 10^{-3}$ and $9.5 \times 10^{-5}$ to $1.7 \times 10^{-3}$, respectively. High HRQs were observed in Huainan, Kunming and Mudanjiang in both summer and winter, whereas Chaohu, Shenyang and Lanzhou had high HRQs only in summer. Enrofloxacin was the main risk component in Kunming in both winter and summer, and in Huainan, Chaohu, Mudanjaing in the summer. Ciprofloxacin was the main risk component in Huainan, Chaohu, Mudanjiang in summer. Roxithromycin was the main risk component in Mudanjiang in winter and in Lanzhou in summer, and sarafloxacin was the main risk component in Chaohu during the summer.

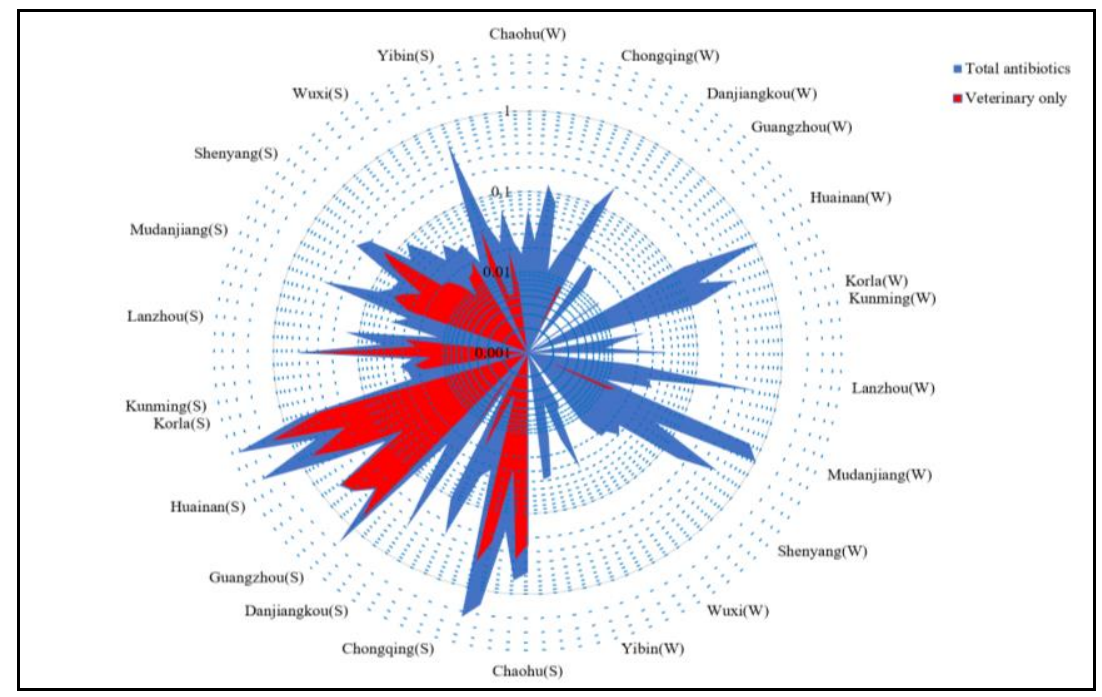

Figure 5. Contribution of exposure to veterinary antibiotics to total antibiotic exposure through drinking water by city and season. W, winter; $S$, summer

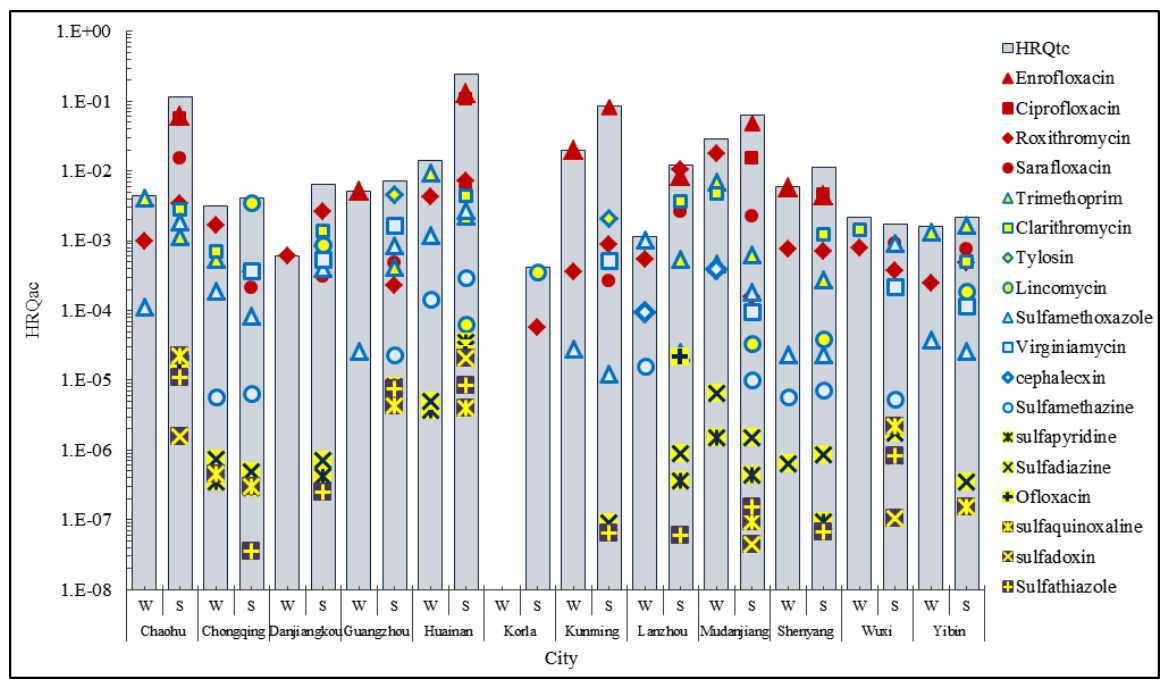

Figure 6. $H R Q_{a c}$ and $H R Q_{t c}$ profiles of detected antibiotics in drinking water by city and season. $H R Q_{a c}$, maximum health risk quotient of the antibiotic among all sampling points in the city; $H R Q_{t c}$, total $H R Q$ in each city; $W$, winter; $S$, summer 


\section{Discussion}

In this study of antibiotic residues in drinking water from 12 cities in China, it was observed that large differences between regions and between summer and winter samples. Guangzhou, Chaohu and Huainan had the highest antibiotic levels in drinking water during the summer. Guangzhou is in the Pearl River Delta region located in South China and has among the highest antibiotic emission densities in China (Zhang et al., 2015). Chaohu and Huainan are in the Huaihe River watershed in eastern China and have the second highest antibiotic emission densities (Zhang et al., 2015). Exposure to antibiotics varied in summer and winter mainly because the dominant residues detected in drinking water. Among the dominant antibiotics detected during the summer months, tylosin, enrofloxacin and sarafloxacin are used only in veterinary medicine, indicating a significant contribution from increased usage of antibiotics in livestock, poultry breeding and aquaculture (Yang et al., 2011; He et al., 2016). The concentration of tylosin in drinking water in Guangzhou $(6.82 \mathrm{ng} / \mathrm{L}$ to $15.04 \mathrm{ng} / \mathrm{L})$ was higher than the residue level found in North Carolina, USA (4 ng/L, Ye et al., 2007). Although concentrations of SAs were relatively low in the summer compared to QNs and MLs, SAs did have high detection rates in both summer and winter, with high concentrations in Mudanjiang during winter. Sulfadiazine is widely used in veterinary medicine (Zheng et al., 2012). Sulfamethoxazole and sulfadiazine were grouped together, as sulfamethoxazole is used in veterinary medicine as well as in human medicine in China (Zhang et al., 2012).

The population of the 12 cities included in this study was generally exposed to antibiotics via water used for drinking and household purposes. Chaohu, Huainan and Guangzhou had summertime exposure doses that were more than five times the summertime exposures in other cities, whereas Mudanjiang had relatively high exposure doses in winter. Generally, human exposure to antibiotics comes from three sources: direct utilization, drinking water, and food (Wang et al., 2017). Urinary antibiotic levels were investigated in a general population study of adults aged 19 to 65 in Korea. Based on creatinine-adjusted urinary levels, the median daily intakes of sulfamethazine, trimethoprim, enrofloxacin and roxithromycin were estimated at $0.61 \mathrm{ng} / \mathrm{kg} / \mathrm{day}$, $0.054 \mathrm{ng} / \mathrm{kg} /$ day, $0.66 \mathrm{ng} / \mathrm{kg} /$ day, and $0.045 \mathrm{ng} / \mathrm{kg} /$ day, respectively, for men, and $0.73 \mathrm{ng} / \mathrm{kg} /$ day, $0.092 \mathrm{ng} / \mathrm{kg} /$ day, $0.71 \mathrm{ng} / \mathrm{kg} /$ day, $0.10 \mathrm{ng} / \mathrm{kg} /$ day, respectively, for women ( $\mathrm{Ji}$ et al., 2010). The exposure contributions from drinking water to levels of these four antibiotics were $24 \%, 1.6 \%, 10 \%$, and $46 \%$ for men and $11 \%, 1.5 \%, 9 \%$ and $26 \%$ for women. Sulfapyridine and sulfaquinoxaline, which are used only for animals, were not detected in meat, milk or aquatic products in Shanghai (Wang et al., 2017), indicating that the main exposure pathway for these two antibiotics is through drinking water, with particularly high exposures in winter. Some studies indicated that long-time boiling can break antibiotics residues in food (Tian et al., 2017). However, the effect of short-time boiling for antibiotic residues remove had not been well explored. In this study, drinking water boiling and indirect intake of water by food domestic cooking (such as rice and noodle) was not included. Additionally, this study evaluated the exposure in good weather in summer and winter, not considering the effect of rainny and snowy weather on water quality. Human exposure to antibiotics via medication use, food consumption and drinking water have not been well explored at the global level, and further investigation is required to improve understanding of the relative contribution of each of these pathways. 
The HRQs of antibiotics varied across the different cities included in the study. Huainan, Chaohu, Kunming and Mudanjiang had relatively high HRQs in the summer, largely because the main antibiotic residues in these cities were enrofloxacin and ciprofloxacin, which had more restrictive ADIs for resistance selection pressure than other antibiotics. Among the four antibiotics with HRQ $\geq 0.01$, enrofloxacin and sarafloxacin are used only in veterinary medicine, whereas ciprofloxacin and roxithromycin are used in both human and veterinary medicine. The use of ciprofloxacin on animals in China is restricted, but in light of poor supervision, ciprofloxacin is still widely detected in water (including drinking water), soil, and food (Li et al., 2012; Xu et al., 2015; Wang et al., 2017). Based on the findings of our study, all the antibiotics detected posed a health risk less than $100 \%$, though several posed significant risks. However, there are potential uncertainties in our analyses. Toxicities stemming from chronic exposure to trace amounts of antibiotic mixtures are not yet well understood (Rodriguez-Mozaz and Weinberg, 2010). Moreover, our assessment considered the relative source contribution (RSC) of ADIs from drinking water usage to be $100 \%$ based on a previous study (Leung et al., 2013). Based on a conservative estimate of RSC of $20 \%$, the HRQs of antibiotics would increase five-fold, and these antibiotics would then pose potential health risks in Huainan during the summer $\left(\mathrm{HRQ}_{\mathrm{ct}}>1\right)$.

\section{Conclusion}

This study quantifies the seasonal and spatial distributions of 23 antibiotics in drinking water from 12 cities in different water basins in China. Exposure to antibiotics via drinking water and its potential risk are described. In light of the widespread detection of antibiotics in potable water, it appears that drinking water constitutes the main pathway for human exposure to antibiotics (especially veterinary antibiotics) in China. Among the antibiotics measured in our study, enrofloxacin, ciprofloxacin, roxithromycin and sarafloxacin were identified as posing the largest risk to human health. Moreover, there need further researches on adverse effects induced by exposure to antibiotics among sensitive groups such as children and pregnant women. The risk of antibiotic resistance by antibiotic exposure via drinking water also needs further studies for more precise evaluation.

\section{Recommendations}

Of 23 antibiotics measured, more than eight were detected in all 12 cities investigated, with the exception of Korla during the summer, indicating widespread population exposure to antibiotics via drinking water. Upgrading current treatment technologies of DWTPs is a possible mitigation measure ( $\mathrm{Li}$ et al., 2018). Further test and evaluation of advanced treatments like ozonation, GAC filtration, nanofiltration and reverse osmosis need to be conducted (Yang et al., 2017). Controlling antibiotic inputs to water source is also highly recommended. Insufficient sewage treatment is a dominant factor explaining contamination of Chinese water sources ( $\mathrm{Li}$ et al., 2014). Improved waste water treatment and control of the treatment process have to be employed for removal of these contaminants, and more research is needed to evaluate their behavior and fate in aquatic environment. 
Restriction of antibiotic usage at national level would like to be an effective measure to reduce the emission of antibiotics. In our study, enrofloxacin, ciprofloxacin, roxithromycin and sarafloxacin were identified as posing the largest risk to human health. Two of these antibiotics were used only in veterinary medicine, indicating a significant contribution from increased usage of antibiotics in livestock, poultry breeding and aquaculture. Restriction of veterinary antibiotic usage in agriculture and aquaculture would likely lead to reduced human exposure to antibiotics via drinking water, especially during the summer. Further study is needed to ascertain the causes of antibiotic usages and to make practical regulations for reducing the usage.

Improved supervision, surveillance and management plan should be implemented to limit the unnecessary use of antibiotics, especially in veterinary medicine. A comprehensive behavioral change communication strategy is central to the success of reduce risks of antibiotics exposure. Specific plans should be designed to restrict the use of antibiotic with high HRQ. Increased supervision is warranted to limit the usage of these antibiotics and to monitor their levels in drinking water.

Acknowledgements. This research is supported by the National Key R\&D Program of China [2018YFC0407502, 2016YFD0801004]; the Science and Technology Project of Beautiful China Ecological Civilization Construction [XDA23100403]; and the Young Elite Scientist Sponsorship Program of Beijing Association for Science and Technology (2020-2022).

\section{REFERENCES}

[1] Aga, D. S., Lenczewski, M., Snow, D., Muurinen, J., Sallach, J. B., Wallace, J. S. (2016): Challenges in the measurement of antibiotics and in evaluating their impacts in agroecosystems: a critical review. - Journal of Environment Quality 45(2): 407419. https://doi.org/10.2134/jeq2015.07.0393.

[2] Bedford, M. (2000): Removal of antibiotic growth promoters from poultry diets: implications and strategies to minimise subsequent problems. - World's Poultry Science Journal 56(4): 347-365.

[3] Bengtsson-Palme, J., Larsson, D. G. J. (2016): Concentrations of antibiotics predicted to select for resistant bacteria: proposed limits for environmental regulation. Environment International 86: 140-149. https://doi.org/10.1016/j.envint.2015.10.015.

[4] Benotti, M. J., Trenholm, R. A., Vanderford, B. J., Holady, J. C., Stanford, B. D., Snyder, S. A. (2009): Pharmaceuticals and endocrine disrupting compounds in U.S. drinking water. - Environmental Science \& Technology 43(3): 597-603. https://doi.org/10.1021/es801845a.

[5] Brown, T. N., Armitage, J. M., Egeghy, P., Kircanski, I., Arnot, J. A. (2016): Dermal permeation data and models for the prioritization and screening-level exposure assessment of organic chemicals. - Environment International 94: 424-435. https://doi.org/10.1016/j.envint.2016.05.025.

[6] Carmona, E., Andreu, V., Picó, Y. (2014): Occurrence of acidic pharmaceuticals and personal care products in Turia River Basin: from waste to drinking water. - Science of the Total Environment 484: 53-63. https://doi.org/10.1016/j.scitotenv.2014.02.085.

[7] China EPA. (2009): Exposure Factors Handbook of Chinese Population. - China Environmental Press, Beijing.

[8] de Jesus Gaffney, V., Almeida, C. M. M., Rodrigues, A., Ferreira, E., Benoliel, M. J., Cardoso, V. V. (2015): Occurrence of pharmaceuticals in a water supply system and 
related human health risk assessment. - Water Research 72: 199-208. https://doi.org/10.1016/j.watres.2014.10.027.

[9] Duan, X. L., Zhang, W. J., Wang, Z. S., Guo, Y. M., Zhang, Y. S., Zhang, J. L. (2010): Water related activity and dermal exposure factors of people in typical areas of Northern China. - Research of Environmental Sciences 23(1): 55-61. https://doi.org/10.13198/j.res.2010.01.57.duanxl.009.

[10] Gullberg, E., Cao, S., Berg, O. G., Ilbäck, C., Sandegren, L., Hughes, D., Andersson, D. I. (2011): Selection of resistant bacteria at very low antibiotic concentrations. PLoS Pathogens 7(7): e1002158. https://doi.org/10.1371/journal.ppat.1002158.

[11] He, X., Deng, M., Wang, Q., Yang, Y., Yang, Y., Nie, X. (2016): Residues and health risk assessment of quinolones and sulfonamides in cultured fish from Pearl River Delta, China. - Aquaculture (Amsterdam, Netherlands) 458: 38-46. https://doi.org/10.1016/j.aquaculture.2016.02.006.

[12] Huang, C., Ding, X., Zhang, L., Zhou, W. (2017): Analysis on drinking water exposure in Wuxi residents. - Journal of Environmental Hygiene 7(2): 95-101. https://doi.org/10.13421/j.cnki.hjwsxzz.2017.02.003.

[13] Ji, K., Kho, Y., Park, C., Paek, D., Ryu, P., Paek, D., Kim, M., Kim, P., Choi, K. (2010): Influence of water and food consumption on inadvertent antibiotics intake among general population. - Environmental Research 110(7): 641-649. https://doi.org/10.1016/j.envres.2010.06.008.

[14] Knapp, C. W., Dolfing, J., Ehlert, P. A. I., Graham, D. W. (2010): Evidence of increasing antibiotic resistance gene abundances in archived soils since 1940. $\begin{array}{llll}\text { Environmental Science } \& \quad \text { Technology 44(2): 580-587. } & \text { \& }\end{array}$ https://doi.org/10.1021/es901221x.

[15] Kümmerer, K. (2009): Antibiotics in the aquatic environment-a review-part I. Chemosphere 75(4): 417-434. https://doi.org/10.1016/j.chemosphere.2008.11.086.

[16] Le Page, G., Gunnarsson, L., Snape, J., Tyler, C. R. (2017): Integrating human and environmental health in antibiotic risk assessment: a critical analysis of protection goals, species sensitivity and antimicrobial resistance. - Environment International 109: 155-169. https://doi.org/10.1016/j.envint.2017.09.013.

[17] Leung, H. W., Jin, L., Wei, S., Tsui, M. M. P., Zhou, B., Jiao, L., Cheung, P. C., Chun, Y. K., Murphy, M. B., Lam, P. K. S. (2013): Pharmaceuticals in tap water: human health risk assessment and proposed monitoring framework in China. Environmental Health Perspectives 121(7): 839-846. https://doi.org/10.1289/ehp.1206244.

[18] Li, W., Shi, Y., Gao, L., Liu, J., Cai, Y. (2012): Occurrence of antibiotics in water, sediments, aquatic plants, and animals from Baiyangdian Lake in North China. Chemosphere 89(11): 1307-1315. https://doi.org/10.1016/j.chemosphere.2012.05.079.

[19] Li, X., Shi, H., Li, K., Zhang, L., Gan, Y. (2014): Occurrence and fate of antibiotics in advanced wastewater treatment facilities and receiving rivers in Beijing, China. Frontiers of Environmental Science \& Engineering 8(6): 888-894. https://doi.org/10.1007/s11783-014-0735-0.

[20] Li, G., Yang, H., An, T., Lu, Y. (2018): Antibiotics elimination and risk reduction at two drinking water treatment plants by using different conventional treatment techniques. - Ecotoxicology and Environmental Safety 158: 154-161. https://doi.org/10.1016/j.ecoenv. 2018.04.019.

[21] Lv, J., Zhang, L., Chen, Y., Ye, B., Han, J., Jin, N. (2019): Occurrence and distribution of pharmaceuticals in raw, finished, and drinking water from seven large river basins in China. - Journal of Water and Health 17(3): 477-489. https://dx.doi.org/10.2166/wh. 2019.250.

[22] Ma, Y., Li, M., Wu, M., Li, Z., Liu, X. (2015): Occurrences and regional distributions of 20 antibiotics in water bodies during groundwater recharge. - Science of the Total Environment 518-519: 498-506. https://doi.org/10.1016/j.scitotenv.2015.02.100. 
[23] Rodriguez-Mozaz, S., Weinberg, H. S. (2010): Meeting report: pharmaceuticals in water - an interdisciplinary approach to a public health challenge. - Environmental Health Perspectives 118(7): 1016-1020. https://doi.org/10.1289/ehp.0901532.

[24] Sarmah, A. K., Meyer, M. T., Boxall, A. B. A. (2006): A global perspective on the use, sales, exposure pathways, occurrence, fate and effects of veterinary antibiotics (VAs) in the environment. $\quad$ - Chemosphere 65(5): 725-759. https://doi.org/10.1016/j.chemosphere.2006.03.026.

[25] ten Berge, W. (2010): QSARs for skin permeation of chemicals. https://home.wxs.nl/ wtberge/qsarperm.html.

[26] Tian, L., Khalil, S., Bayen, S. (2017): Effect of thermal treatments on the degradation of antibiotic residues in food. - Critical Reviews in Food Science and Nutrition 57(17): 3760. https://doi.org/10.1080/10408398.2016.1164119.

[27] Wang, H., Ren, L., Yu, X., Hu, J., Chen, Y., He, G., Jiang, Q. (2017): Antibiotic residues in meat, milk and aquatic products in Shanghai and human exposure $\begin{array}{lllll}\text { assessment. } & - & \text { Food } & \text { Control }\end{array}$ https://doi.org/10.1016/j.foodcont.2017.04.034.

[28] Xu, Y., Chen, T., Wang, Y., Tao, H., Liu, S., Shi, W. (2015): The occurrence and removal of selected fluoroquinolones in urban drinking water treatment plants. Environmental Monitoring and Assessment 187(12): 729. https://doi.org/10.1007/s10661-015-4963-y.

[29] Xu, Z., Li, T., Bi, J., Wang, C. (2018): Spatiotemporal heterogeneity of antibiotic pollution and ecological risk assessment in Taihu Lake Basin, China. - Science of the Total Environment 643: 12-20. https://doi.org/10.1016/j.scitotenv.2018.06.175.

[30] Yang, J. F., Ying, G. G., Zhao, J. L., Tao, R., Su, H. C., Liu, Y. S. (2011): Spatial and seasonal distribution of selected antibiotics in surface waters of the Pearl Rivers, China. - Journal of Environmental Science and Health, Part B 46(3): 272-280. https://doi.org/10.1080/03601234.2011.540540.

[31] Yang, Y., Sik Ok, Y., Kim, K. H., Kwon, E. E., Tsang, Y. F. (2017): Occurrences and removal of pharmaceuticals and personal care products (PPCPs) in drinking water and water/sewage treatment plants: a review. - Science of the Total Environment 596597: 303-320. http://dx.doi.org/10.1016/j.scitotenv.2017.04.102.

[32] Ye, Z., Weinberg, H. S., Meyer, M. T. (2007): Trace analysis of trimethoprim and sulfonamide, macrolide, quinolone, and tetracycline antibiotics in chlorinated drinking water using liquid chromatography electrospray tandem mass spectrometry. - Analytical Chemistry 79(3): 1135-1144. https://doi.org/10.1021/ac060972a.

[33] Zhang, R., Zhang, G., Tang, J., Xu, W., Li, J., Liu, X., Zou, Y., Chen, X., Li, X. (2012): Levels, spatial distribution and sources of selected antibiotics in the East River (Dongjiang), South China. - Aquatic Ecosystem Health \& Management 15(2): 210-218. https://doi.org/10.1080/14634988.2012.689576.

[34] Zhang, Q. Q., Ying, G. G., Pan, C. G., Liu, Y. S., Zhao, J. L. (2015): Comprehensive evaluation of antibiotics emission and fate in the river basins of China: source analysis, multimedia modeling, and linkage to bacterial resistance. - Environmental Science \& Technology 49(11): 6772-6782. https://doi.org/10.1021/acs.est.5b00729.

[35] Zheng, Q., Zhang, R., Wang, Y., Pan, X., Tang, J., Zhang, G. (2012): Occurrence and distribution of antibiotics in the Beibu Gulf, China: impacts of river discharge and aquaculture activities. - Marine Environmental Research 78: 26-33. https://doi.org/10.1016/j.marenvres.2012.03.007. 


\section{APPENDIX \\ Risk assessment of prevalence of antibiotics in drinking water and impacts on human health exposed to antibiotic contamination - China}

Analysis method (Lv et al., 2019)

\section{Sample extraction}

Target analytes were extracted from the water samples using SPE. One liter water samples were acidified to $\mathrm{pH}$ 2.0-2.5 with phosphoric acid and potassium phosphate monobasic. The samples were spiked with isotopically labeled standards, at a concentration of $20 \mathrm{ng}$, and $500 \mathrm{mg}$ EDTA-2Na were added. Detailed information on internal standards is shown in Table Al.

The water samples were loaded on the automated SPE system at an approximate rate of $5 \mathrm{~mL} / \mathrm{min}$ (Visiprep-DL 24-Ports SPE Vacuum Manifold, Supelco, USA). Oasis hydrophilic-lipophilic balance (HLB) cartridges $(6 \mathrm{~mL}, 200 \mathrm{mg}$ of sorbent, Waters, USA) were used for sample pretreatment. The cartridges were conditioned with $10 \mathrm{~mL}$ methanol and $10 \mathrm{~mL}$ ultrapure water prior to sample loading. After sample loading, the cartridges were rinsed with $10 \mathrm{~mL}$ ultrapure water, dried for 10 min under vacuum and eluted with $10 \mathrm{~mL}$ methanol. The eluates were concentrated to near dryness under a gentle stream of nitrogen in a $30{ }^{\circ} \mathrm{C}$ water bath and reconstituted in $1 \mathrm{~mL}$ of water/methanol $(95 / 5 ; \mathrm{v} / \mathrm{v})$. The concentrated extracts were then analyzed by UPLCMS/MS.

\section{UPLC-MS/MS analysis}

A UPLC system (ACQUITY UPLC, Waters, USA) equipped with a Waters ACQUITY UPLC HSS T3 column $(100 \mathrm{~mm} \times 2.1 \mathrm{~mm}$ and $1.8 \mu \mathrm{m}$ particle size $)$ was used to separate the analytes. The column temperature was $40{ }^{\circ} \mathrm{C}$, the injection volume was $10 \mu \mathrm{L}$, and the flow rate was $0.35 \mathrm{~mL} / \mathrm{min}$. The mobile phases consisted of water with $0.1 \%(\mathrm{v} / \mathrm{v})$ formic acid (A) and methanol (B), and the following elution program was employed: $95 \%$ (A) to $80 \%$ (A) from 0 to $3 \mathrm{~min}, 80 \%$ to $70 \%$ (A) from 3 to $6 \mathrm{~min}$, $70 \%$ to $60 \%$ (A) from 6 to $10 \mathrm{~min}, 60 \%$ to $30 \%$ (A) from 10 to $12 \mathrm{~min}, 30 \%$ to $5 \%$ (A) from 12 to $15 \mathrm{~min}$, and then $95 \%$ (A) from 15 to $15.5 \mathrm{~min}$. Finally, the column was reequilibrated for $2.5 \mathrm{~min}$ before the next injection, for a total run time of $18 \mathrm{~min}$.

A Waters TQ-S micro triple quadrupole mass spectrometer (Waters Technologies, USA) equipped with an electrospray ion source was used for the analysis of the pharmaceuticals. Multiple reaction monitoring (MRM) mode was used for quantitative analysis, and all pharmaceuticals were measured in positive ion mode. The source temperature was $120{ }^{\circ} \mathrm{C}$, the desolvation temperature was $350{ }^{\circ} \mathrm{C}$, the desolvation gas flow was $650 \mathrm{~L} / \mathrm{h}$, the collision gas flow was $50 \mathrm{~L} / \mathrm{h}$, and the capillary voltage was $2.0 \mathrm{kV}$.

\section{Method performance and quality assurance}

The determination of linearity, LOD and LOQ, recovery and precision were used to validate the method. Calibration curves were generated using mixtures of standards at concentrations from 0.05 to $100 \mu \mathrm{g} / \mathrm{L}$ and isotopically-labeled internal standards at a 
concentration of $20 \mu \mathrm{g} / \mathrm{L}$. Good linearity was observed, with correlation coefficients greater than 0.99 .

The analytes were identified by their retention times, two characteristic ion transitions and specific ion ratios (deviation $<20 \%$ with respect to analytical standard ratios). Spiked ultrapure water with various concentrations were extracted and analyzed to determine the LOD and LOQ. The LOD and LOQ were defined as the lowest concentrations that gave signal-to-noise ratios greater than 3 and 10, respectively.

Field blanks and method blanks were created to identify any contaminant from the sampling site and analysis process. Recovery and precision were used to validate the method performance. Percent recovery and precision were determined using ultrapure water and spiked matrix samples (raw water and finished water) at three concentrations $(5,10$, and $40 \mathrm{ng} / \mathrm{L})$ and the IS solution $(20 \mathrm{ng} / \mathrm{L})$. Six replicates of each concentration were used to evaluate the analyte recovery during sample pretreatment and UPLCMS/MS analysis. The recoveries as expressed as the average of six replicates. The recoveries and precision varied with the natures of the analytes, and an acceptable result was generated (U.S. EPA, 2007).

Table A1. Detailed information about target analytes standards and internal standards. $\beta L s$, $\beta$-lactams; MLs, macrolides; SAs, sulfonamides; QNs, fluoroquinolones; LN, lincosamide;

$G P$, glycopeptide. IS, Internal standard

\begin{tabular}{|c|c|c|c|c|}
\hline Antibiotics & CAS No. & Class of antibiotics & Molecular formula & Molecular weight \\
\hline Penicillin G & $61-33-6$ & $\beta \mathrm{Ls}$ & $\mathrm{C}_{16} \mathrm{H}_{17} \mathrm{~N}_{2} \mathrm{O}_{4} \mathrm{~S}$ & 334.39 \\
\hline Cloxacillin & $61-72-3$ & $\beta \mathrm{Ls}$ & $\mathrm{C}_{19} \mathrm{H}_{18} \mathrm{ClN}_{3} \mathrm{O}_{5} \mathrm{~S}$ & 435.88 \\
\hline Cephalecxin & $23325-78-2$ & $\beta$ Ls & $\mathrm{C}_{16} \mathrm{H}_{17} \mathrm{~N}_{3} \mathrm{O}_{4} \mathrm{~S}$ & 365.4 \\
\hline Ceftiofur & $80370-57-6$ & $\beta \mathrm{Ls}$ & $\mathrm{C}_{19} \mathrm{H}_{17} \mathrm{~N}_{5} \mathrm{O}_{7} \mathrm{~S}_{3}$ & 523.56 \\
\hline Clarithromycin & $81103-11-9$ & MLs & $\mathrm{C}_{38} \mathrm{H}_{69} \mathrm{NO}_{13}$ & 747.95 \\
\hline Roxithromycin & 80214-83-1 & MLs & $\mathrm{C}_{41} \mathrm{H}_{76} \mathrm{~N}_{2} \mathrm{O}_{15}$ & 837.05 \\
\hline Tylosin & $1401-69-0$ & MLs & $\mathrm{C}_{46} \mathrm{H}_{77} \mathrm{NO}_{17}$ & 916.1 \\
\hline Sulfapyridine & $144-83-2$ & SAs & $\mathrm{C}_{11} \mathrm{H}_{11} \mathrm{~N}_{3} \mathrm{O}_{2} \mathrm{~S}$ & 249.29 \\
\hline Sulfadiazine & $68-35-9$ & SAs & $\mathrm{C}_{10} \mathrm{H}_{10} \mathrm{~N}_{4} \mathrm{O}_{2} \mathrm{~S}$ & 250.28 \\
\hline Sulfamethoxazole & $723-46-6$ & SAs & $\mathrm{C}_{10} \mathrm{H}_{11} \mathrm{~N}_{3} \mathrm{O}_{3} \mathrm{~S}$ & 253.28 \\
\hline Sulfathiazole & $72-14-0$ & SAs & $\mathrm{C}_{9} \mathrm{H}_{9} \mathrm{~N}_{3} \mathrm{O}_{2} \mathrm{~S}_{2}$ & 255.32 \\
\hline Sulfamethazine & $57-68-1$ & SAs & $\mathrm{C}_{12} \mathrm{H}_{14} \mathrm{~N}_{4} \mathrm{O}_{2} \mathrm{~S}$ & 278.33 \\
\hline Sulfaquinoxaline & $59-40-5$ & SAs & $\mathrm{C}_{14} \mathrm{H}_{12} \mathrm{~N}_{4} \mathrm{O}_{2} \mathrm{~S}$ & 300.34 \\
\hline Sulfadoxin & $2447-57-6$ & SAs & $\mathrm{C}_{12} \mathrm{H}_{14} \mathrm{~N}_{4} \mathrm{O}_{4} \mathrm{~S}$ & 310.33 \\
\hline Trimethoprim & $738-70-5$ & SAs & $\mathrm{C}_{14} \mathrm{H}_{18} \mathrm{~N}_{4} \mathrm{O}_{3}$ & 290.32 \\
\hline Norfloxacin & $70458-96-7$ & QNs & $\mathrm{C}_{16} \mathrm{H}_{18} \mathrm{FN}_{3} \mathrm{O}_{3}$ & 319.33 \\
\hline Ciprofloxacin & $85721-33-1$ & QNs & $\mathrm{C}_{17} \mathrm{H}_{18} \mathrm{FN}_{3} \mathrm{O}_{3}$ & 331.34 \\
\hline Enrofloxacin & $93106-60-6$ & QNs & $\mathrm{C}_{19} \mathrm{H}_{22} \mathrm{FN}_{3} \mathrm{O}_{3}$ & 359.39 \\
\hline Ofloxacin & $82419-36-1$ & QNs & $\mathrm{C}_{18} \mathrm{H}_{20} \mathrm{FN}_{3} \mathrm{O}_{4}$ & 361.37 \\
\hline Clinafloxacin & $105956-97-6$ & QNs & $\mathrm{C}_{17} \mathrm{H}_{17} \mathrm{ClFN}_{3} \mathrm{O}_{3}$ & 365.79 \\
\hline Sarafloxacin & 98105-99-8 & QNs & $\mathrm{C}_{20} \mathrm{H}_{17} \mathrm{~F}_{2} \mathrm{~N}_{3} \mathrm{O}_{3}$ & 385.36 \\
\hline Lincomycin & $154-21-2$ & $\mathrm{LN}$ & $\mathrm{C}_{18} \mathrm{H}_{34} \mathrm{~N}_{2} \mathrm{O}_{6} \mathrm{~S}$ & 406.54 \\
\hline Virginiamycin & $11006-76-1$ & GP & $\mathrm{C}_{28} \mathrm{H}_{35} \mathrm{~N}_{3} \mathrm{O}_{7}$ & 525.59 \\
\hline $\mathrm{D}_{8}$-Ciprofloxacin & - & IS & $\mathrm{C}_{17} \mathrm{H}_{10} \mathrm{D}_{8} \mathrm{FN}_{3} \mathrm{O}_{3}$ & 339.39 \\
\hline${ }^{13} \mathrm{C}_{6}$ Sulfamethazine & - & IS & $\mathrm{C}_{6}{ }^{13} \mathrm{C}_{6} \mathrm{H}_{14} \mathrm{~N}_{4} \mathrm{O}_{2} \mathrm{~S}$ & 284.29 \\
\hline${ }^{13} \mathrm{C}_{3}$-Trimethoprim & - & IS & $\mathrm{C}_{11}{ }^{13} \mathrm{C}_{3} \mathrm{H}_{18} \mathrm{~N}_{4} \mathrm{O}_{3}$ & 293.3 \\
\hline${ }^{13} \mathrm{C}$ - $\mathrm{D}_{3}$-Erythromycin & - & IS & $\mathrm{C}_{36}{ }^{13} \mathrm{CH}_{64} \mathrm{D}_{3} \mathrm{NO}_{13}$ & 737.94 \\
\hline $\mathrm{D}_{3}$-Lincomycin & - & IS & $\mathrm{C}_{18} \mathrm{H}_{31} \mathrm{D}_{3} \mathrm{~N}_{2} \mathrm{O}_{6} \mathrm{~S}$ & 409.56 \\
\hline $\mathrm{D}_{5}$-cephalexcin & - & IS & $\mathrm{C}_{16} \mathrm{H}_{14} \mathrm{D}_{5} \mathrm{~N}_{3} \mathrm{O}_{4} \mathrm{~S}$ & 370.43 \\
\hline${ }^{13} \mathrm{C}_{6}$-Sulfamethoxazole & - & IS & $\mathrm{C}_{4}{ }^{13} \mathrm{C}_{6} \mathrm{H}_{11} \mathrm{~N}_{3} \mathrm{O}_{3} \mathrm{~S}$ & 259.21 \\
\hline $\mathrm{D}_{8}$-Sarafloxacin & 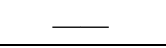 & IS & $\mathrm{C}_{20} \mathrm{H}_{9} \mathrm{D}_{8} \mathrm{~F}_{2} \mathrm{~N}_{3} \mathrm{O}_{3}$ & 393.4 \\
\hline
\end{tabular}


Table A2. IngR values corresponding to area, season and sex in China

\begin{tabular}{|c|c|c|c|}
\hline Area & Season & Gender & IngR (L/day) \\
\hline Liaoning & winter & male & 1742 \\
\hline Heilongjiang & winter & male & 1881 \\
\hline Jiangsu & winter & male & 2267 \\
\hline Anhui & winter & male & 2944 \\
\hline Hubei & Winter & Male & 1500 \\
\hline Guangdong & Winter & Male & 1695 \\
\hline Chongqing & Winter & Male & 1215 \\
\hline Sichuan & Winter & Male & 1862 \\
\hline Yunnan & Winter & Male & 1895 \\
\hline Gansu & Winter & Male & 2587 \\
\hline Xinjiang & Winter & Male & 2974 \\
\hline Liaoning & Summer & Male & 2090 \\
\hline Heilongjiang & Summer & Male & 2196 \\
\hline Jiangsu & Summer & Male & 3204 \\
\hline Anhui & Summer & Male & 4063 \\
\hline Hubei & Summer & Male & 2570 \\
\hline Guangdong & Summer & Male & 2411 \\
\hline Chongqing & Summer & Male & 2053 \\
\hline Sichuan & Summer & Male & 3184 \\
\hline Yunnan & Summer & Male & 2719 \\
\hline Gansu & Summer & Male & 3990 \\
\hline Xinjiang & Summer & Male & 3716 \\
\hline Liaoning & Winter & Female & 1425 \\
\hline Heilongjiang & Winter & Female & 2180 \\
\hline Jiangsu & Winter & Female & 1817 \\
\hline Anhui & Winter & Female & 2432 \\
\hline Hubei & Winter & Female & 1366 \\
\hline Guangdong & Winter & Female & 1663 \\
\hline Chongqing & Winter & Female & 1293 \\
\hline Sichuan & Winter & Female & 1691 \\
\hline Yunnan & Winter & Female & 1492 \\
\hline Gansu & Winter & Female & 2050 \\
\hline Xinjiang & Winter & Female & 2086 \\
\hline Liaoning & Summer & Female & 1706 \\
\hline Heilongjiang & Summer & Female & 1826 \\
\hline Jiangsu & Summer & Female & 2558 \\
\hline Anhui & Summer & Female & 3423 \\
\hline Hubei & Summer & Female & 2376 \\
\hline Guangdong & Summer & Female & 2347 \\
\hline Chongqing & Summer & Female & 2164 \\
\hline Sichuan & Summer & Female & 3062 \\
\hline Yunnan & Summer & Female & 2203 \\
\hline Gansu & Summer & Female & 3133 \\
\hline Xinjiang & Summer & Female & 2703 \\
\hline
\end{tabular}


Table A3. The skin surface area available for contact $\left(\mathrm{cm}^{2}\right)$

\begin{tabular}{c|c|c|c|c|c|c|c|c}
\hline $\mathbf{S A}_{\mathbf{i}}\left(\mathbf{c m}^{\mathbf{2}}\right)$ & $\begin{array}{c}\text { Hand } \\
\text { cleaning }\end{array}$ & $\begin{array}{c}\text { Face and hair } \\
\text { cleaning }\end{array}$ & $\begin{array}{c}\text { Foot } \\
\text { cleaning }\end{array}$ & Dish washing & $\begin{array}{c}\text { Vegetable } \\
\text { washing }\end{array}$ & $\begin{array}{c}\text { Clothes } \\
\text { washing }\end{array}$ & Bathing & Swimming \\
\hline Male & 800 & 1300 & 1100 & 800 & 800 & 800 & 17000 & 6300 \\
Female & 700 & 1200 & 1000 & 700 & 700 & 700 & 15000 & 5700 \\
\hline
\end{tabular}

Table A4. The time of contact (T, hours/day) on water usage habits in northern and southern China

\begin{tabular}{c|c|c|c|c|c|c|c|c}
\hline $\begin{array}{c}\text { Time of contact } \\
\text { (hours/day) }\end{array}$ & $\begin{array}{c}\text { Hand } \\
\text { cleaning }\end{array}$ & $\begin{array}{c}\text { Face and hair } \\
\text { cleaning }\end{array}$ & $\begin{array}{c}\text { Foot } \\
\text { cleaning }\end{array}$ & $\begin{array}{c}\text { Dishes } \\
\text { washing }\end{array}$ & $\begin{array}{c}\text { Vegetable } \\
\text { washing }\end{array}$ & $\begin{array}{c}\text { Clothes } \\
\text { washing }\end{array}$ & Bathing & Swimming \\
\hline Male in South China & 0.0500 & 0.0783 & 0.0167 & 0.0000 & 0.0000 & 0.0000 & 0.1750 & 0.086 \\
Female in South China & 0.0667 & 0.1117 & 0.0117 & 0.0850 & 0.0717 & 0.0467 & 0.2083 & 0.088 \\
Male in North China & 0.0627 & 0.1012 & 0.0146 & 0.0115 & 0.0091 & 0.0462 & 0.2553 & 0.086 \\
Female in North China & 0.0614 & 0.1168 & 0.0165 & 0.1606 & 0.1364 & 0.3050 & 0.2424 & 0.088 \\
\hline
\end{tabular}

Table A5. Kow and MW of target antibiotics

\begin{tabular}{c|c|c}
\hline Antibiotic & log Kow & MW (g/mol) \\
\hline Penicillin G & 1.83 & 334.38 \\
Cloxacillin & 2.44 & 435.88 \\
Cephalecxin & 0.65 & 347.39 \\
Ceftiofur & 1.6 & 523.57 \\
Clarithromycin & 3.16 & 747.95 \\
Roxithromycin & 2.21 & 837.05 \\
Tylosin & 1.63 & 916.11 \\
Sulfapyridine & 0.35 & 249.29 \\
Sulfadiazine & 2.59 & 250.27 \\
Sulfamethoxazole & 0.89 & 253.28 \\
Sulfathiazole & 0.05 & 255.32 \\
Sulfamethazine & 0.14 & 278.33 \\
Sulfaquinoxaline & 1.68 & 300.34 \\
Sulfadoxin & 0.43 & 310.33 \\
Norfloxacin & 0.46 & 319.33 \\
Ciprofloxacin & 0.28 & 331.34 \\
Enrofloxacin & 0.64 & 359.4 \\
Ofloxacin & -0.39 & 371.37 \\
Sarafloxacin & 0.57 & 385.36 \\
Lincomycin & 0.2 & 406.54 \\
Trimethoprim & 0.91 & 290.32 \\
\hline
\end{tabular}

Table A6. Sex ratios for each city

\begin{tabular}{c|c}
\hline City & Gender ratio (population of male/population of female) \\
\hline Chaohu & 0.5162 \\
Chongqing & 0.5127 \\
Danjiangkou & 0.5158 \\
Guangzhou & 0.5016 \\
Huainan & 0.525 \\
Kuerle & 0.5109 \\
Kunming & 0.5141 \\
Lanzhou & 0.5037 \\
Mudanjiang & 0.501 \\
Shenyang & 0.4941 \\
Wuxi & 0.5033 \\
Yibin & 0.5197 \\
\hline
\end{tabular}


Table A7. The acceptable daily intake (ADI) or risk-specific dose (RSD) used for $H R Q$ calculation of each antibiotic

\begin{tabular}{c|c|c}
\hline Antibotic & $\begin{array}{c}\text { ADI or RSD } \\
\text { (ug/kg/day) }\end{array}$ & Toxicity or effect endpoint \\
\hline Cephalecxin & 0.13 & Resistance selection \\
Clarithromycin & 0.0083 & Resistance selection \\
Roxithromycin & 0.033 & Resistance selection \\
Tylosin & 0.13 & Resistance selection \\
Sulfapyridine & 10 & Microbiological \\
Sulfadiazine & 20 & Reduced fetal bodyweight and C-R length at the next higher dose \\
Sulfamethoxazole & 0.5 & Resistance selection \\
Sulfathiazole & 50 & Changes in thyroid tissue. a NOEL of 5 mg/kg for the thyroid effects in animal studies \\
Sulfamethazine & 1.6 & Thyroid gland follicular adenoma in rats with tumor incidence data \\
Sulfaquinoxaline & 10 & Increased thyroid weights at the next higher dose \\
Sulfadoxin & 50 & Increased liver weights at the next higher dose \\
Norfloxacin & 0.017 & Resistance selection \\
Ciprofloxacin & 0.0021 & Resistance selection \\
Enrofloxacin & 0.0021 & Resistance selection \\
Ofloxacin & 3.2 & Microbiological \\
Sarafloxacin & 0.017 & Resistance selection \\
Lincomycin & 0.067 & Resistance selection \\
Virginiamycin & 0.067 & Resistance selection \\
Trimethoprim & 0.017 & Resistance selection \\
\hline
\end{tabular}

Table A8. The significance level of the antibiotic concentrations across cities and seasons

\begin{tabular}{|c|c|c|c|}
\hline \multirow{2}{*}{ Class of antibiotics } & \multirow{2}{*}{ Nonparametric tests } & \multicolumn{2}{|c|}{ Significance level } \\
\hline & & Across seasons & Across cities \\
\hline$\beta$-lactams & $\begin{array}{l}\text { Mann Whitney U test } \\
\text { Kolmogorov-Smirnov test } \\
\text { Wald Wolfwitz Runs } \\
\text { Median test } \\
\text { Kruskal-Wallis test }\end{array}$ & $\begin{array}{c}0.206 \\
0.001 * \\
- \\
- \\
\end{array}$ & $\begin{array}{l}\overline{ } \\
\overline{ } \\
0.0001^{*} \\
0.0001^{*}\end{array}$ \\
\hline Macrolides & $\begin{array}{l}\text { Mann Whitney U test } \\
\text { Kolmogorov-Smirnov test } \\
\text { Wald Wolfwitz Runs } \\
\text { Median test } \\
\text { Kruskal-Wallis test }\end{array}$ & $\begin{array}{c}0.065 \\
0.007^{*} \\
0.002 * \\
- \\
\end{array}$ & $\begin{array}{l}\overline{-} \\
\overline{-} \\
0.0001 * \\
0.0001 *\end{array}$ \\
\hline Sulfonamides & $\begin{array}{l}\text { Mann Whitney U test } \\
\text { Kolmogorov-Smirnov test } \\
\text { Wald Wolfwitz Runs } \\
\text { Median test } \\
\text { Kruskal-Wallis test }\end{array}$ & $\begin{array}{l}0.0001 * \\
0.0001 * \\
0.0001 * \\
\square \\
\end{array}$ & $\begin{array}{l}\overline{ } \\
\overline{ } \\
0.0001^{*} \\
0.0001^{*}\end{array}$ \\
\hline Fuoroquinolones & $\begin{array}{l}\text { Mann Whitney U test } \\
\text { Kolmogorov-Smirnov test } \\
\text { Wald Wolfwitz Runs } \\
\text { Median test } \\
\text { Kruskal-Wallis test }\end{array}$ & $\begin{array}{l}0.0001 * \\
0.0001 * \\
0.0001 * \\
\square \\
\end{array}$ & $\begin{array}{c}\overline{ } \\
\overline{ } \\
0.0001^{*} \\
0.015^{*}\end{array}$ \\
\hline Lincosamide & $\begin{array}{l}\text { Mann Whitney U test } \\
\text { Kolmogorov-Smirnov test } \\
\text { Wald Wolfwitz Runs } \\
\text { Median test } \\
\text { Kruskal-Wallis test }\end{array}$ & $\begin{array}{c}0.0001 * \\
0.187 \\
0.0001 * \\
- \\
\end{array}$ & $\begin{array}{l}\overline{ } \\
\overline{ } \\
0.0001^{*} \\
0.0001^{*}\end{array}$ \\
\hline Glycopeptide & $\begin{array}{l}\text { Mann Whitney U test } \\
\text { Kolmogorov-Smirnov test } \\
\text { Wald Wolfwitz Runs } \\
\text { Median test } \\
\text { Kruskal-Wallis test }\end{array}$ & $\begin{array}{c}0.0001^{*} \\
0.034^{*} \\
0.0001^{*} \\
\square \\
\end{array}$ & $\begin{array}{l}\overline{-} \\
\overline{-} \\
0.0001 * \\
0.0001^{*}\end{array}$ \\
\hline
\end{tabular}

Mann Whitney U test, Kolmogorov-Smirnov test and Wald Wolfwitz Runs were conducted for the seasonal differences between winter and summer; Median test and Kruskal-Wallis test were conducted for the spatial differences across 12 cities. $*$ The significance level is 0.05 